\title{
Pimpinella saxifraga (Apiaceae): A new record from Jejudo Island, Korea
}

\author{
Chunghee LEE, Yujin SONG, Yun-Chang JEON, Hee-Young GIL ${ }^{\mathbf{1}}$ and Seon-Hee KIM ${ }^{\mathbf{1}}$
}

Department of Gardens Education, Korea National Arboretum, Pocheon 11186, Korea

${ }^{1}$ Department of Biological Sciences, Sungkyunkwan University, Suwon 16419, Korea

(Received 18 December 2017; Revised 6 March 2018; Accepted 18 March 2018)

\begin{abstract}
Pimpinella saxifraga L. (Scarlet pimpernel or Burnet saxifrage), a newly introduced species, was found from Baekyakyi oreum (a parasitic cone or cinder cone) in Seogwipo, Jejudo Island. This species is native to Europe and western Asia and is reported as a widely invasive species around the world. Pimpinella saxifraga is distinguished from other related Korean taxa by leaves that are pinnately compound with $3 ? 7$ pairs of segments, which vary from simple, ovate, to 2-pinnatisect, with linear lobes. The vernacular name of "Baek-yak-yi-cham-na-mul" was assigned after the name of the cinder cone where it was initially discovered. We provide descriptions of the morphological characters, photographs and a key to allied taxa in Korea. The geographical origin and introduction routes are unknown, but it is highly likely that it was introduced as fodder given its high nutritious value for sheep and cattle or as a medicinal herb. This species invades commonly grasslands and woodlands and prefers dry, well-drained, and calcareous soils. The distribution of this species was analyzed by searching extensively in surrounding Baekyakyi oreum and adjacent cinder cones, but no other populations were observed. It is protected commonly at the edges or inside of the patchy pine forest in the cinder cone from grazing by cattle; given the worldwide invasive nature of this species, special monitoring and management plans should be developed.
\end{abstract}

Keywords: Pimpinella saxifraga, Apiaceae, Jeju Island, cinder cone, invasive species

The genus Pimpinella L. (Apiaceae) includes about 150-170 species and is disjunct between Africa, Asia, and Europe (Pimenov and Leonov, 1993; Pu and Watson, 2005). It is one of the largest genera in Apiaceae and considered as taxonomically complex genus due to its wide geographical range and diverse morphological variation (Abebe, 1992). Small and rather featureless fruits are the general characteristics of this genus (Pu and Watson, 2005). The last revision of this genus was conducted by Wolff (1927), and three sections were recognized based on petal colour, fruit and petal vestiture and life history characteristics.

Five species and one variety of this genus, $P$. brachycarpa (Kom.) Nakai var. brachycarpa, P. brachycarpa (Kom.) Nakai var. uchiyamana (Y. Yabe ex Nakai) W. T. Lee \& G. J. Jang, P. komarovii (Kitag.) R. H. Shan \& F. T. Pu, and P. kroeana (Y. Yabe) Nakai, P. hallaisanensis (W. T. Lee \& G. J. Jang) G. J. Jang, W. K. Paik \& W. T. Lee, and P. calycina Maxim. are recently listed in the Korean Peninsula (Park et al., 2017). Lee
(1980) first recognized three species, P. brachycarpa (Kom.) Nakai, P. komarovii (Kitag.) R. H. Shan \& F. T. Pu, and $P$. kroeana (Y. Yabe) Nakai. Jang et al. (1995) found new variety of Pimpinella brachycarpa var. hallaisanensis W. Lee \& G. Jang from Jeju Island and described based on distinct morphological characteristics and different chromosome number (i.e., $2 n=24)$ with $P$. brachycarpa $(2 n=22)$. Comprehensive revision of Pimpinella in Korea was conducted by Jang et al. (1999), in which 4 species and 1 variety of Pimpinella were recognized. Taxonomic rank of $P$. brachycarpa var. hallaisanensis was changed to species level, P. hallaisanensis (W. Lee \& G. Jang) G. Jang, W. Paik \& W. Lee and $P$. koreana was treated as synonym of $P$. brachycarpa based on their morphological study results. Since taxonomic entity of $P$. koreana is still controversial, we did not include $P$. koreana for this study and followed recent taxonomic treatment of Pimpinella in Korea (Jang et al, 1999; Park et al., 2017).

\footnotetext{
*Author for correspondence: aganolee@korea.kr
} 
During an expedition to the Baekyakyi Oreum in Seogwipo, Jeju Island, we found a newly introduced species of Pimpinella. Baekyakyi Oreum is a small cinder cone with the highest peak of $356 \mathrm{~m}$ above sea level. It is characterized by two vegetation types that cover this cinder cone, plantation forest of Cryptomeria japonica (Thunb. ex L. f.) D. Don in south-western part and meadows vegetated by several species (i.e., Cirsium rhinoceros (H. Lév. \& Vaniot) Nakai, Lonicera japonica Thunb., Elsholtzia ciliata (Thunb.) Hyl., Isodon joponicus (Burm.) H. Hara, Pteridium aquilinum (Thunb.) Siebold var. latiusculum (Desv.) Underw. ex Hell., and etc.). Although we could not measure the exact population size of this introduced species, it was found frequently in two-thirds of the whole areas of Baekyakyi Oreum. The vernacular name of "Baek-yak-yicham-na-mul" was assigned after the name of cinder cone where it was first discovered. In this study, Pimpinella saxifraga is reported as a newly founded taxon in Korea. In addition, we provide its description of morphological characters, illustrations, and photographs of $P$. saxifraga and a key to allied taxa in Korea.

\section{Taxonomic Treatment}

Pimpinella saxifraga L., Sp. Pl. 163, 1753 (Figs. 1, 2, Table 1).

Korean name: Baek-yak-yi-cham-na-mul (백약이참나물). Plants perennial herbs, up to $60 \mathrm{~cm}$, somewhat pubescent. Roots thickened fusiform, sturdy. Stems erect, solitary to branched, usually terete, either entirely hairy or rarely glabrous. Leaves alternate, stalked, glabrous to hairy; basal leaves pinnate, 3-7 pairs of segments, ovate with toothed margins, persistent at anthesis, petioles 10-20 cm long; cauline leaves 2 times pinnate with linear lobes, almost leafless above, sessile on sheaths. Inflorescence a compound umbel, round-topped, 5-8 cm in diam.; rays 6-25, ascending, glabrous; bracts absent, rarely 1-4, bracteoles absent, rarely $5-8$. Flowers white, rarely pinkish or purplish, polygamous, $5 \mathrm{~mm}$ in diam.; petals 5 , ca. $1 \mathrm{~mm}$ long, apex recurved; calyx vestigial; stamens 5; pistil 2 fused carpels; styles 2 . Fruits long schizocarp, broadly ovoid, 2 parted, ridges not prominent, glabrous, dark brown, 2-2.5 mm long, $1.5-2 \mathrm{~mm}$ wide. Chromosome number $2 n=40$.

Flowering: Jun to Aug.

Distribution: Jeju Island, Korea. [Europe, North America, Western Asia].

Voucher specimens: KOREA. Jeju-do: Seogwipo-si, Pyoseon-myeon, Seongeup-ri, Baekyakyi Oreum, elev. 324 m,
22 Jul 2016, C. Lee et al. KNKB2017-1 (KH).

Taxonomic notes: Pimpinella saxifraga originally occurs in Europe, Western Asia ranging to the Baikal area and north eastern parts of North America (Hämet-Ahti, 1980). Its original habitat was known as coastal areas and inland in dry broad-leaved forests and rocky slopes. However, it also occurs in human disturbed area, such as meadows, fields, and roads (Wells et al., 1976; Hämet-Ahti, 1980; Grime et al., 1988). We found one population of this species at the Baekyakyi Oreum, which is located in eastern part of Jeju Island. The distribution of this species was searched extensively in surrounding Baekyakyi Oreum and adjacent cinder cones, but no other population has been observed.

Morphological characters of the species are very variable. This species is distinguished from other related Korean taxa by leaves that are pinnately compound with 3-7 pairs of segments (Table 1). The geographical origin and introduction routes are unknown, but it is highly likely that it was introduced as fodder given high nutritious value for sheep and cattle or as medicinal herb. This species invades commonly grasslands and woodlands and prefers dry, well drained, and calcareous soils. It is protected commonly in the edge or inside of patchy pine forest in the cinder cone from grazing by cattle and, given worldwide invasive nature of this species, special monitoring and management plans should be developed.

\section{A key to Pimpinella saxifraga and its related taxa in Korea}

1. Leaves pinnately compound

$$
\text { P. saxifraga (백약이참나물) }
$$

1. Leaves ternate ……………………………………….... 2

2. Basal leaves persistent at anthesis; rays 7-9

P. hallaisanensis (한라참나물)

2. Basal leaves withered at anthesis; rays $5-15$ …… 3

3. Bracts 3-5, linear; mericarps 5-5.8 $\mathrm{mm}$ long ....... P. calycina (큰산참나물)

3. Bracts absent; mericarps 2-2.5 mm long ……… 4 4. Roots fusiform, upper leaves 1-3 ternate; flowers not polygamous

P. komarovii (노루참나물)

4. Roots fibrous, upper leaves ternate; flowers polygamous ……………………………… 5

5. Uppermost leaf not deeply dissected ……....

. P. brachycarpa var. brachycarpa (참나물)

5. All leaves deeply dissected …………….........

P. brachycarpa var. uchiyamana (그늘참나물) 


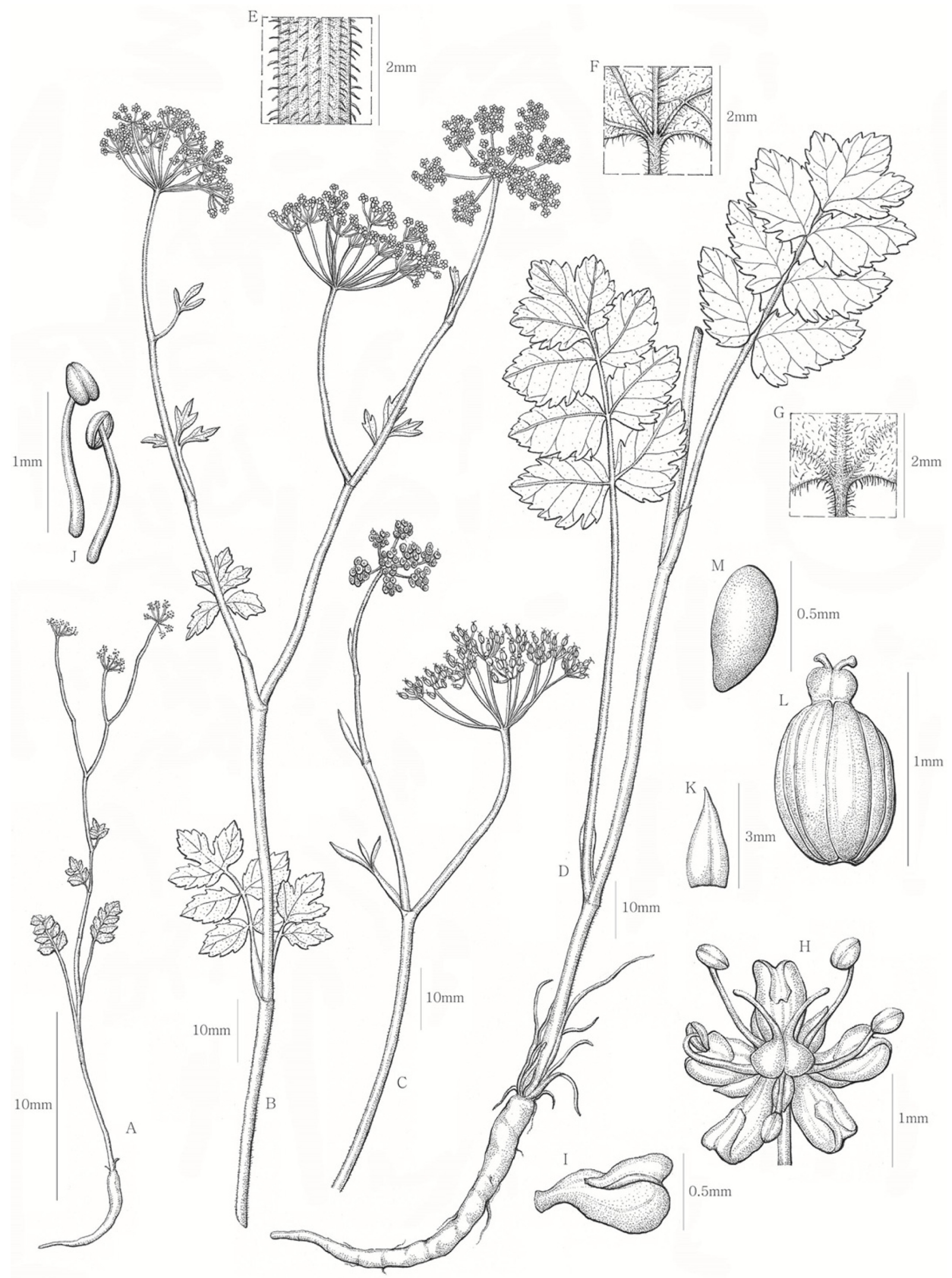

Fig. 1. Illustration of Pimpinella saxifraga. A. Habit. B. Flowering branch. C. Fruiting branch. D. Root with branch. E. Stem. F. Abaxial view of leaf. G. Adaxial view of leaf. H. Flower. I. Petal. J. Stamen. K. Calyx. L. Fruit. M. Seed. 

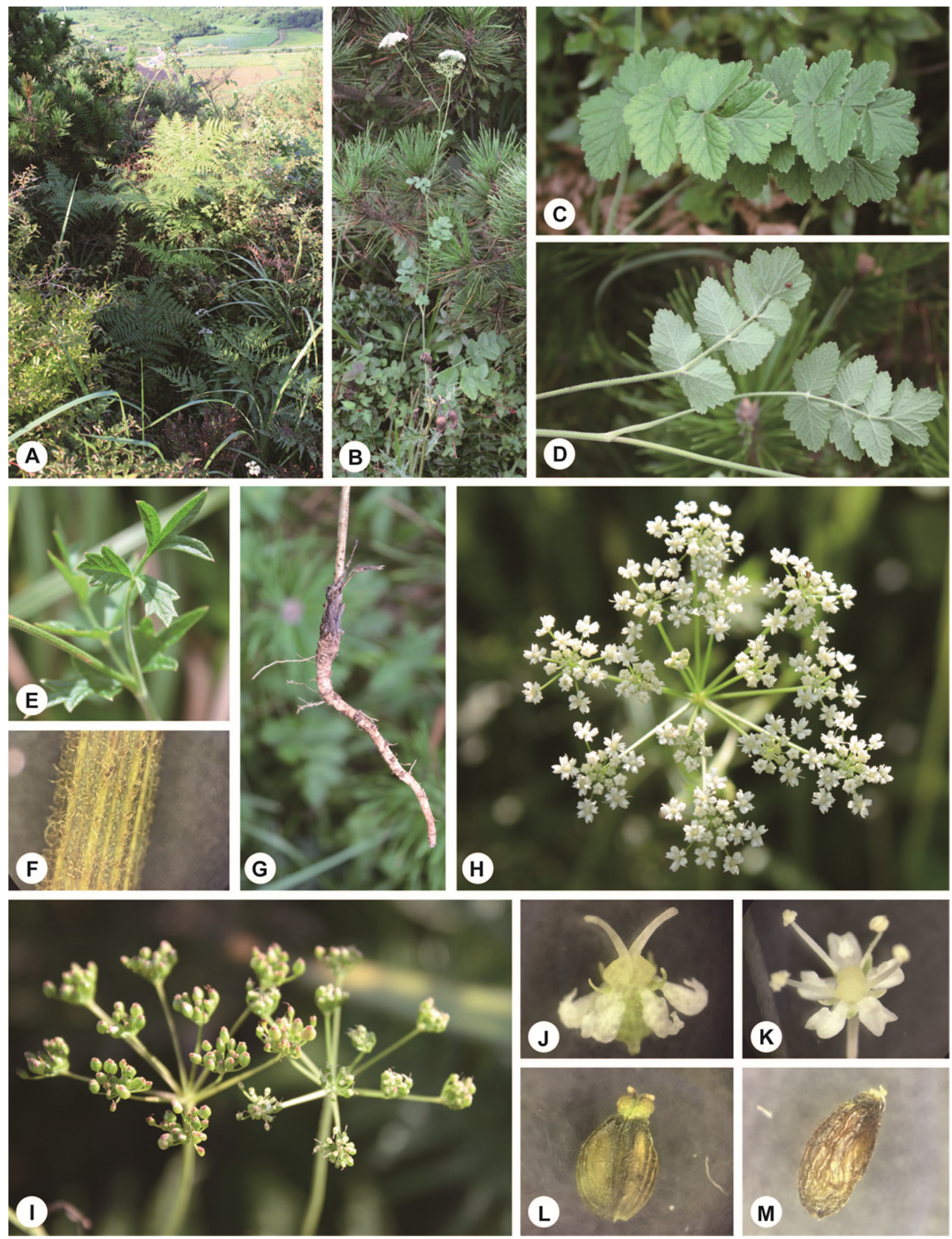

Fig. 2. Morphological characters of Pimpinella saxifraga. A. Habitat. B. Habit. C. Adaxial surface of leaf. D. Abaxial surface of leaf. E. Stem leaves. F. Stem. G. Root. H. Inflorescence. I. Fruits. J. Female flower. K. Male flower. L. Fruit. M. Seed. 
Table 1. Morphological characteristics of Pimpinella species in Korea (Jang et al., 1999; Pu and Watson, 2005; Lee, 2007).

\begin{tabular}{|c|c|c|c|c|c|c|}
\hline Taxa & Height & Root & Leaves & Rays & $\begin{array}{l}\text { Polygamous } \\
\text { flower }\end{array}$ & $\begin{array}{c}\text { Persistence of basal } \\
\text { leaves at anthesis }\end{array}$ \\
\hline P. saxifraga & $20-60 \mathrm{~cm}$ & Fusiform & $\begin{array}{l}\text { Pinnately } \\
\text { compound } \\
\text { (3-7 pairs) }\end{array}$ & $6-25$ & O & $\times$ \\
\hline P. brachycarpa var. brachycarpa & $70-85 \mathrm{~cm}$ & Fibrous & Ternate & $7-15$ & $\bigcirc$ & $x$ \\
\hline P. brachycarpa var. uchiyamana & $50-100 \mathrm{~cm}$ & Fibrous & $\begin{array}{c}\text { Ternate } \\
\text { (deeply dissected) }\end{array}$ & $7-15$ & $\bigcirc$ & $x$ \\
\hline P. koreana & $40-60 \mathrm{~cm}$ & Fibrous & $1-2$ ternate & $5-15$ & $\bigcirc$ & $x$ \\
\hline P. komarovii & $1 \mathrm{~m}$ & Fusiform & 1-3 ternate & $9-15$ & $x$ & $\times$ \\
\hline P. hallaisanensis & $20-50 \mathrm{~cm}$ & Fibrous & $1-2$ ternate & $7-9$ & - & $\bigcirc$ \\
\hline
\end{tabular}

\section{Conflict of Interest}

Authors declare that there is no conflict of interest.

\section{Acknowledgments}

This work was supported by a grant from the Korea National Arboretum (KNA3-1-8, 15-5). We thank Seung-Chul Kim at Sungkyunkwan University for field assistance and helpful discussion.

\section{Literature Cited}

Abebe, D. 1992. Systematic studies in the genus Pimpinella L. (Umbelliferae) from tropical Africa. Botanical Journal of the Linnean Society 110: 327-372.

Grime, J. P., J. G. Hodgson and R. Hunt. 1988. Comparative Plant Ecology: A Functional Approach to Common British Species. Unwin Hyman, London, 742 pp.

Hämet-Ahti, L. 1980. Pukinjuuri-Pimpinella saxifraga L. In Suuri kasvikirja III. Jalas, J. (ed.), Otava, Keuruu. Pp. 216217.

Jang, G., W. Paik and W. Lee. 1995. Pimpinella brachycarpa var. hallaisanensis (Apiaceae): a new variety from Korea. Korean
Journal of Plant Taxonomy 25: 7-12. (in Korean)

Jang, G., W. Paik and W.-T. Lee. 1999. Taxonomy of the genus Pimpinella (Umbelliferae) in Korea. Korean Journal of Plant Taxonomy 29: 151-167. (in Korean)

Lee, T. B. 1980. Illustrated Flora of Korea. Hyangmun Co., Seoul, 990 pp. (in Korean)

Park, C.-W., B.-Y. Lee, J.-H. Song and K. Kim. 2017. Pimpinella. In Flora of Korea Vol. 5c. Rosidae: Rhamnaceae to Apiaceae. Flora of Korea Editorial Committee (ed.), National Istitute of Biological Resources, Incheon. Pp. 116-120.

Pimenov, M. G. and M. V. Leonov. 1993. Genera of the Umbelliferae. Royal Botanic Gardens, Kew, 156 pp.

$\mathrm{Pu}, \mathrm{F}$. and M. F. Watson. 2005. Pimpinella. In Flora of China. Vol. 14. Wu, Z. Y., P. H. Raven and D. Y. Hong (eds.), Science Press, Beijing and Missouri Botanical Garden Press, St. Louis, MO. Pp. 93-104.

Wells, T. C. E., J. Sheail, D. F. Ball and L. K. Ward. 1976. Ecological studies on the porton ranges: relationships between vegetation, soils and land-use history. Journal of Ecology 64: 589-626.

Wolff, H. 1927. Umbelliferae-Apioideae-Ammineae-Carinae, Ammineae Novemjugatae et Genuinae. In Das Pflanzenreich, Heft 90 (IV. 228). Engler, A. (ed.), W. Engelmann, Berlin. Pp. $1-398$. 